\title{
A casual occurrence of Physostegia virginiana (Lamiaceae) in Poland
}

Artur Pliszko

A casual occurrence of Physostegia virginiana (Lamiaceae) in Poland. - Acta Mus. Siles. Sci. Natur. 65: 47-50, 2016.

\begin{abstract}
This short note provides data on casual occurrence of Physostegia virginiana in Poland. It was found on abandoned allotments in the western part of the town of Skarżysko-Kamienna in 2015 (ATPOL cartogram unit: EE45). Its population consists of 153 generative ramets growing in three clumps. The habitat suggests that the plant probably escaped from cultivation with dumped garden waste.
\end{abstract}

Key words: Physostegia virginiana, casual alien, ornamental plant, distribution, Poland.

\section{Introduction}

Physostegia virginiana (L.) Benth., a rhizomatous perennial herb of the family Lamiaceae, is native to temperate regions of North America, including eastern United States, eastern Canada, and northeastern Mexico (Cantino 1982). It was divided by Cantino (1982) into two subspecies, namely $P$. virginiana subsp. virginiana and $P$. virginiana subsp. praemorsa (Shinners) P.D. Cantino. Apart from the differences in the size of flowers and leaves, these two subspecies have different geographical distributions and occupy different habitats. The type subspecies extends from Quebec to Manitoba, south to northeastern Kansas, southern Illinois, northern Tennessee, and eastern Virginia, and is usually found along the edges of rivers, lakes, and ditches, whereas the subspecies praemorsa is distributed from western Virginia and central North Carolina to southeastern New Mexico and northeastern Coahuila, north to central Missouri, northern Illinois, and northwestern Ohio, and is usually found in prairies and on open woodland slopes (Cantino 1981, 1982).

In the $17^{\text {th }}$ century $P$. virginiana was taken into cultivation in Europe, and nowadays is widely cultivated as an ornamental in gardens and for cut-flower production (Cantino 1982, Cardin et al. 2002, Whiteley 2011). There are many cultivars (Whiteley 2011) that can be use, for example, in herbaceous and mixed borders (Phillips 1956). Physostegia virginiana was recorded as a garden escape or casual alien in many countries in the world, and furthermore, it became a naturalised species in France, Japan, and Australia (Randall 2012 and references cited therein). In Poland, it is treated only as a cultivated plant (Mirek et al. 2002), being found in flower gardens and cemeteries (Czarna et al. 2006, Bożek 2008, Dębicz 2012). This short note provides data on casual occurrence of $P$. virginiana in Poland.

\section{Material and methods}

Physostegia virginiana was identified using morphological features given by Cantino $(1981,1982)$ and Whiteley (2011). Identification of associated vascular plant species followed Rutkowski (2004) and Sun et al. (2010). Distribution map was prepared using the ATPOL cartogram method (Zając 1978). Geographicalhistorical status followed Mirek et al. (2002) and Tokarska-Guzik et al. (2012). Syntaxonomical data followed Matuszkiewicz (2008). Voucher specimens of $P$. virginiana are deposited in the Herbarium of the Institute of Botany of the Jagiellonian University in Kraków (KRA 0451649 - 0451652). 


\section{Results}

Physostegia virginiana was discovered in October 2015 on abandoned allotments between Paryska Street and Ląkowa Street in the western part of the town of SkarżyskoKamienna, south-central Poland. It grows here in three dispersed clumps (GPS coordinates: $51^{\circ} 6^{\prime} 57,84^{\prime \prime} \mathrm{N} / 20^{\circ} 50^{\prime} 51,54^{\prime \prime} \mathrm{E}, 51^{\circ} 6^{\prime} 58,14^{\prime \prime} \mathrm{N} / 20^{\circ} 50^{\prime} 51,66^{\prime \prime} \mathrm{E}$, and $51^{\circ} 7^{\prime} 3^{\prime \prime} \mathrm{N} / 20^{\circ} 50^{\prime} 53,83^{\prime \prime} \mathrm{E}$ ), near the adjacent cultivated allotments. Presented site lies within the unit EE45 of the ATPOL cartogram grid (Fig. 1). Altogether, the population consists of 153 generative ramets (flowering or fruiting stems) (Fig. 2). In this anthropogenic habitat, which is under secondary succession, associated vascular plants are mainly represented by native species typical of meadow communities of the class Molinio-Arrhenatheretea (e.g. Agrostis gigantea Roth, Dactylis glomerata L., Deschampsia caespitosa (L.) P. Beauv., Holcus lanatus L., Juncus effusus L., Lotus uliginosus Schkuhr, Potentilla anserina L., and Rumex crispus L.). There are also associated alien plants, including a few species established in the Polish flora (e.g. Aster novae-angliae L., Lysimachia punctata L., and Solidago canadensis L.) and one species under cultivation in Poland, namely Miscanthus sacchariflorus (Maxim.) Hack.

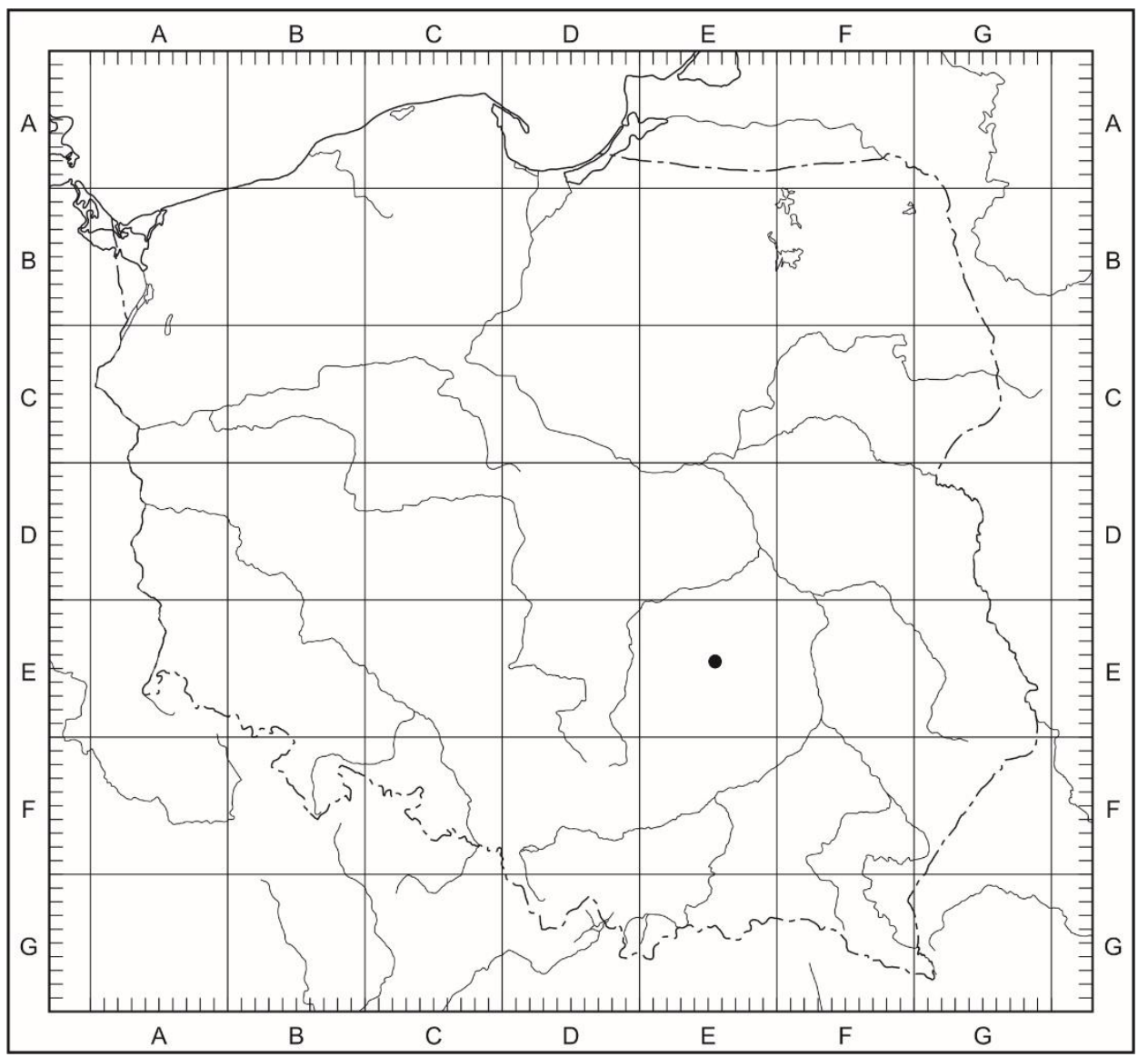

Fig 1: Distribution of Physostegia virginiana in Poland.

\section{Discussion}

The occurrence of Physostegia virginiana on abandoned allotments, which are located close to the adjacent cultivated allotments, suggests that the plant probably escaped from cultivation with dumped garden waste. Taking into consideration the definitions of alien plants by Pyšek et al. (2004), P. virginiana currently is a casual alien plant in Poland but its status may change in the future. Its local persistence and spread need further study. The plant 
shows the clonal growth and relatively small native range. These two factors promote the transitioning of alien plants from casual to naturalised (Milbau \& Stout 2008). In Australia, this species is naturalised on roadsides, and appears to spread via rhizomes and possibly by seed dispersal (Hosking et al. 2007). In Japan, it is treated as an invasive plant (Mito \& Uesugi 2004). Moreover, it is also worth mentioning that, comparing the new records with the recent floristic data (Maciejczak 1988, Nobis 2007, Podgórska 2011), P. virginiana and its associated species Miscanthus sacchariflorus are new to the flora of the town of SkarżyskoKamienna.

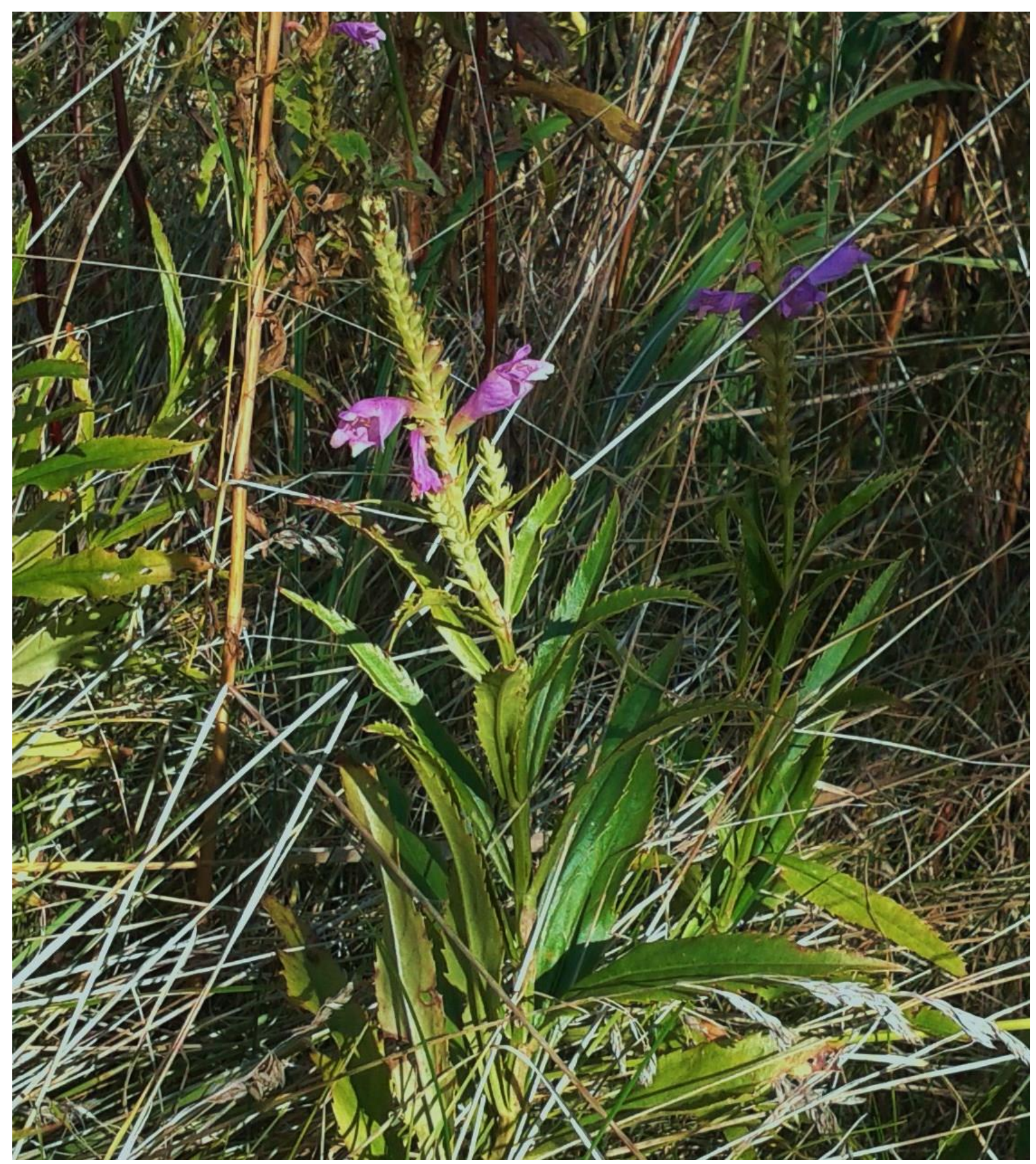

Fig 2: Physostegia virginiana on abandoned allotments in Skarżysko-Kamienna, south-central Poland (Photo by A. Pliszko, 4 October 2015). 


\section{References}

Bożek M. (2008): Pollen yield and pollen grain dimensions of some late-summer plant species of the Lamiaceae family. - J. Apic. Sci. 52(1): 31-36.

Cantino P.D. (1981): Change of status for Physostegia virginiana var. ledinghamii (Labiatae) and evidence for a hybrid origin. - Rhodora 83: 111-118.

- (1982): A monograph of the genus Physostegia (Labiatae). - Contr. Gray Herb. 211: 1-105.

Cardin L., Onesto J. P. \& Moury B. (2002): First report of Alfalfa mosaic virus in Physostegia virginiana. Plant Dis. 86(1): 72.4-72.4.

Czarna A., Piskorz R. \& Wyrzykiewicz-Raszewska M. (2006): Vascular plants on selected Catholic cemeteries of Jelenia Góra and its surroundings. - Rocz. AR Pozn. 378, Bot.-Stec. 10: 69-86.

Dębicz R. (2012): Zieleń cmentarzy w krajobrazie wsi Dolnego Śląska. Uniwersytet Przyrodniczy we Wrocławiu, Wrocław, $311 \mathrm{pp}$.

Hosking J.R., Conn B.J., Lepschi B.J. \& Barker C.H. (2007): Plant species first recognised as naturalised for New South Wales in 2002 and 2003, with additional comments on species recognised as naturalised in 2000-2001. - Cunninghamia 10(1): 139-166.

Maciejczak B. (1988): Flora synantropijna Kielc, Skarżyska-Kamiennej i Starachowic. Kieleckie Towarzystwo Naukowe, Kielce, 162 pp.

Matuszkiewicz W. (2008): Przewodnik do oznaczania zbiorowisk roślinnych Polski. Wydawnictwo Naukowe PWN, Warszawa, 537 pp.

Milbau A. \& Stout J.C. (2008): Factors associated with alien plants transitioning from casual, to naturalized, to invasive. - Conserv. Biol. 22(2): 308-317.

Mirek Z., Piękoś-Mirkowa H., Zając A. \& Zając M. (2002): Flowering plants and pteridophytes of Poland, a checklist. W. Szafer Institute of Botany, Polish Academy of Sciences, Kraków, 442 pp.

Mito T. \& Uesugi T. (2004): Invasive alien species in Japan: the status quo and the new regulation for prevention of their adverse effects. - Global Environmental Research 8(2): 171-193.

Nobis M. (2007): Rośliny naczyniowe zachodniej części Przedgórza Iłżeckiego (Wyżyna Małopolska). - Prace Botaniczne 40: 1-458.

Phillips C.E.L. (1956): The small garden. Pan Books, London, 414 pp.

Podgórska M. (2011): Flora roślin naczyniowych Garbu Gielniowskiego (Wyżyna Małopolska). - Prace Botaniczne 44: 1-304.

Pyšek P., Richardson D.M., Rejmánek M., Webster G.L., Williamson M. \& Kirschner J. (2004): Alien plants in checklists and floras: towards better communication between taxonomists and ecologists. Taxon 53(1): 131-143.

Randall R.P. (2012): A global compendium of weeds. $2^{\text {nd }}$ edition. Department of Agriculture and Food, Western Australia, $1119 \mathrm{pp}$.

Rutkowski L. (2004): Klucz do oznaczania roślin naczyniowych Polski niżowej. Wydawnictwo Naukowe PWN, Warszawa, 814 pp.

Sun Q., Lin Q., Yi Z.-L., Yang Z.-R. \& Zhou F.-S. (2010): A taxonomic revision of Miscanthus s. 1. (Poaceae) from China. - Bot. J. Linn. Soc. 164(2): 178-220.

Tokarska-Guzik B., Dajdok Z., Zając M., Zając A., Urbisz A., Danielewicz W. \& Hołdyński C. (2012): Rośliny obcego pochodzenia w Polsce ze szczególnym uwzględnieniem gatunków inwazyjnych. Generalna Dyrekcja Ochrony Środowiska, Warszawa, 197 pp.

Whiteley A.C. (2011): Physostegia Bentham. pp. 90. In: Cullen J., Knees S.G. \& Cubey H.S. (eds): The European garden flora, vol. 5, Boraginaceae to Compositae, $2^{\text {nd }}$ edition. Cambridge University Press, Cambridge, $639 \mathrm{pp}$.

Zając A. (1978): Atlas of distribution of vascular plants in Poland (ATPOL). - Taxon 27(5-6): 481-484.

Author's address: Artur Pliszko, Department of Plant Taxonomy, Phytogeography and Herbarium, Institute of Botany, Jagiellonian University in Kraków, Kopernika 31, 31-501 Kraków, Poland.

E-mail: artur.pliszko@uj.edu.pl 